\title{
Electrical properties of $\mathrm{Bi}_{5} \mathrm{Nb}_{3-3 x} \mathrm{Cr}_{3 x} \mathrm{O}_{15-\delta}$ characterized by impedance spectroscopy
}

\author{
N. A. Sekushin ${ }^{1}$, N. A. Zhuk ${ }^{2, \dagger}$, E. A. Belyaeva ${ }^{2}$, V. A. Belyy ${ }^{1}$, V. A. Grass ${ }^{1}$, M. V. Yermolina ${ }^{3}$ \\ †nzhuck@mail.ru
}

\author{
${ }^{1}$ Institute of Chemistry of Komi Scientific Center, Ural Branch of RAS, Pervomaiskaya, 48, Syktyvkar, 167982, Russia \\ ${ }^{2}$ Syktyvkar State University, Oktyabrsky pr., 55, Syktyvkar, 167001, Russia \\ ${ }^{3}$ University of Illinois Chicago, 845 W. Taylor St., MC 111, Chicago, IL, 60607, United States
}

The majority of bismuth-containing oxide compounds with layered perovskite-like structure are ferroelectric with high Curie temperatures. Bismuth niobate $\mathrm{Bi}_{5} \mathrm{Nb}_{3} \mathrm{O}_{15}$ belongs to the group of layered perovskite-like compounds and is characterized by relaxation-like ferroelectric behavior. Previous studies have shown that bismuth niobate forms a limited range of solid solutions containing atoms of transition elements. In this connection, we studied the influence of the heterovalent substitution of niobium by chromium atoms on the phase transition and electrophysical properties of bismuth niobate. The electrical properties of the polycrystalline samples of bismuth niobate $\mathrm{Bi}_{5} \mathrm{Nb}_{3} \mathrm{O}_{15}$ and chromium-containing solid solutions $\mathrm{Bi}_{5} \mathrm{Nb}_{3-3 x} \mathrm{Cr}_{3 x} \mathrm{O}_{15-\delta}(x \leq 0.08)$ were studied using impedance spectroscopy. Bismuth niobate is crystallized in tetragonal syngony; the solid solutions with $x \geq 0.04$ have a monoclinic distortion of the tetragonal structure. We did not find any phase transitions significantly changing electrical properties of the oxide materials $\mathrm{Bi}_{5} \mathrm{Nb}_{3} \mathrm{O}_{15}$ and $\mathrm{Bi}_{5} \mathrm{Nb}_{3-3 x} \mathrm{Cr}_{3 x} \mathrm{O}_{15-\delta}(x \leq 0.08)$ in the temperature range of $350-600^{\circ} \mathrm{C}$; this can be caused by relaxation character of dielectric polarization and blurring of the phase transition. The equivalent circuits were developed for $\mathrm{Bi}_{5} \mathrm{Nb}_{3} \mathrm{O}_{15}$ and the solid solutions. The circuits consisted of the resistors and two elements for space-distributed polarization. The accuracy of the equivalent circuits was checked by the agreement between the experimental and calculated values. The $\mathrm{Bi}_{5} \mathrm{Nb}_{3-3 x} \mathrm{Cr}_{3 x} \mathrm{O}_{15-\delta}$ samples exhibited dielectric properties with extremely low conductivity at temperatures under $350^{\circ} \mathrm{C}$. At the higher temperature, the materials demonstrated semiconducting properties with the activation energy of the conductivity of $\sim 0.6 \mathrm{eV}$. The performed study allows us to conclude about the mixed electronic-ionic character of conductivity in the $\mathrm{Bi}_{5} \mathrm{Nb}_{3-3 x} \mathrm{Cr}_{3 x} \mathrm{O}_{15-\delta}$.

Keywords: impedance spectroscopy, ferroelectric, Aurivillius phases, solid solutions, phase transition.

\section{Introduction}

Bismuth-containing oxide compounds with layered perovskite-like structure (Aurivillius phases) exhibiting ferro- and piezoelectric properties are, undoubtedly, of both practical and theoretical interest [1-3]. Bismuth niobate $\mathrm{Bi}_{5} \mathrm{Nb}_{3} \mathrm{O}_{15}$ belongs to the group of mixed layered perovskite-like compounds, its structure is characterized by ordered alternation of one and two niobium-oxygen octahedra thick fragments [4-6]. Previous studies have shown that bismuth niobate $\mathrm{Bi}_{5} \mathrm{Nb}_{3} \mathrm{O}_{15}$ forms a limited range of solid solutions with heterovalent substitution containing atoms of $3 \mathrm{~d}$ elements [7-10]. The studies of magnetic dilution in bismuth niobate solid solutions showed that the stabilization of structure of the solid solutions with heterovalent substitution occurs as a result of partial oxidation of paramagnetic atoms or formation of stable exchange-bound aggregates, which character and energy of interatomic interaction are determined by the nature of the paramagnetic atoms.

The present work shows the results of the study of electrophysical characteristics of $\mathrm{Bi}_{5} \mathrm{Nb}_{3} \mathrm{O}_{15}$ and chromiumcontaining solid solutions $\mathrm{Bi}_{5} \mathrm{Nb}_{3-3 x} \mathrm{Cr}_{3 x} \mathrm{O}_{15-\delta}$ using impedance spectroscopy.

\section{Experimental details}

The synthesis of the solid solution samples was performed by the standard ceramic method from "special pure" grade bismuth (III), niobium (V), and chromium (III) oxides at $750^{\circ} \mathrm{C}$ and $1050^{\circ} \mathrm{C}$. The phase composition of the studied preparations was monitored by means of scanning electron microscopy (a scanning electron microscope Tescan VEGA $3 \mathrm{LMN}$, an energy dispersive spectrometer INCA Energy 450) and X-ray phase analysis (a diffractometer DRON4-13, $\mathrm{Cu}_{\mathrm{K} \alpha}$ emission). The unit cell parameters of the solid solutions were calculated using the CSD program package [11]. The quantitative measurement of chromium in the solid solution samples was performed by atom-emission spectrometry (a spectrometer SPECTRO CIROS with inductively coupled plasma), the accuracy was $\pm 5 \%$ of $x$ in the solid solution formula. The thermograms of the solid solutions were obtained by differential scanning calorimetry (Netzsch STA 409 PC Luxx, the Centre of collective use "Khimiya" of the Institute of chemistry of Komi SC UB RAS) in platinum-rhodium crucibles at a heating rate of $10 \mathrm{~K} / \mathrm{min}$. Impedance measurements were performed with the impedancemeter $\mathrm{Z}-1000 \mathrm{P}$ from $1.0 \mathrm{~Hz}$ to $1 \mathrm{MHz}$ in the temperature range from 350 to $600^{\circ} \mathrm{C}$. 


\section{Results and discussion}

\subsection{X-ray and thermal analysis of $\mathrm{Bi}_{5} \mathrm{Nb}_{3-3 x} \mathrm{Cr}_{3 x} \mathrm{O}_{15-\delta}$}

The chromium-containing solid solutions $\mathrm{Bi}_{5} \mathrm{Nb}_{3-3 x} \mathrm{Cr}_{3 x} \mathrm{O}_{15-\delta}$ were obtained at $x \leq 0.08$ (Fig. $1 \mathrm{a}, 1 \mathrm{~b}$ ). Indexing of the diffractograms of bismuth niobate and solid solutions with $x \leq 0.03$ was made based on the space group $\mathrm{P} 4 / \mathrm{mmm}$ $[12,13]$. The unit cell parameters of the solid solutions with $x \leq 0.03$ are close to the bismuth niobate parameters $a=0.5473 \mathrm{~nm}, c=2.097 \mathrm{~nm}(x=0.03)\left(\mathrm{Bi}_{5} \mathrm{Nb}_{3} \mathrm{O}_{15}, a=0.5472\right.$ $\mathrm{nm}, c=2.097 \mathrm{~nm})[4-6,12]$.

The tetragonal unit cell is monoclinically distorted with the increase in concentration of chromium in the solid solutions $(x \geq 0.04)$. The description of the diffractograms was made based on the space group P $2 / \mathrm{m}$. With increasing content of chromium atoms in the solid solutions, the parameter $a$ insignificantly increases to $0.5473 \mathrm{~nm}$, the parameter $b$ decreases to $0.5460 \mathrm{~nm}$, and the angle $\alpha$ is changing from $90.33^{\circ}$ to $91.64^{\circ}(x=0.08)$. The thermograms of $\mathrm{Bi}_{5} \mathrm{Nb}_{3} \mathrm{O}_{15}$ and $\mathrm{Bi}_{5} \mathrm{Nb}_{1.82} \mathrm{Cr}_{0.18} \mathrm{O}_{15-\delta}$ samples (Fig. 1c) were obtained by the method of differential scanning calorimetry. The thermograms show no obvious thermal effects related with the ferroelectric phase transition in the range of $400-600^{\circ} \mathrm{C}$.

\subsection{Impedance spectroscopy of $\mathrm{Bi}_{5} \mathrm{Nb}_{3-3 x} \mathrm{Cr}_{3 x} \mathrm{O}_{15-\delta}$}

Impedance spectra are most often presented as an impedance vector hodograph in the coordinates of real and imaginary parts of the impedance $\left(Z^{\prime},-Z^{\prime \prime}\right)$. To present the impedance in the coordinates of the real capacitance $C_{u}$ and conductivity $\sigma_{u}$, the following formulas should be used [14]:

$$
\sigma_{u}=Z^{\prime} /|Z|^{2} ; \quad C_{u}=-Z^{\prime \prime} / \omega|Z|^{2} .
$$

Here $|Z|=\sqrt{\left(Z^{\prime}\right)^{2}+\left(Z^{\prime \prime}\right)^{2}}$ is the impedance module; $Z^{\prime}$ and $-Z^{\prime \prime}$ are real and imaginary parts of the impedance; $\sigma_{u}$ and $C_{u}$ are conductivity and capacitance of the sample for the parallel substitution scheme; $\omega$ is a circular frequency.

The set of hodographs of one sample in the coordinates $\left(\sigma_{u}, C_{u}\right)$ consists of the isotherms presenting the $C_{u}\left(\sigma_{u}\right)$ dependencies, and the dotted frequency curves called isofrequencies.

If the chosen temperature range has no phase transition, the isotherms and isofrequencies form a net with no breaks and fractures, as it was shown previously [14]. The impedance hodographs of the samples of solid solutions $\mathrm{Bi}_{5} \mathrm{Nb}_{3-3 x} \mathrm{Cr}_{3 x} \mathrm{O}_{15-\delta}(x=0.08,0.06,0.04)$ and $\mathrm{Bi}_{5} \mathrm{Nb}_{3} \mathrm{O}_{15}$ have no features in the logarithmic coordinates. This indicates the absence of phase transitions accompanied by abrupt change of electrical properties in the range of $350-600^{\circ} \mathrm{C}$ (Fig. 2). At the same time, a strong dispersion is observed in the lowfrequency region indicating ions taking part in the sample polarization. The ion activity increases with the rise of temperature. Fig. 3 shows the impedance vector hodographs of $\mathrm{Bi}_{5} \mathrm{Nb}_{3-3 x} \mathrm{Cr}_{3 x} \mathrm{O}_{15-\delta}(x=0.08,0.06)$ and $\mathrm{Bi}_{5} \mathrm{Nb}_{3} \mathrm{O}_{15}$. The samples of the solid solutions proved to be good dielectrics with extremely low conductivity at the temperatures below $350^{\circ} \mathrm{C}$.

The chromium atoms in crystal structure cause the decrease in both the real $\left(Z^{\prime}\right)$ and imaginary $\left(-Z^{\prime \prime}\right)$ impedance
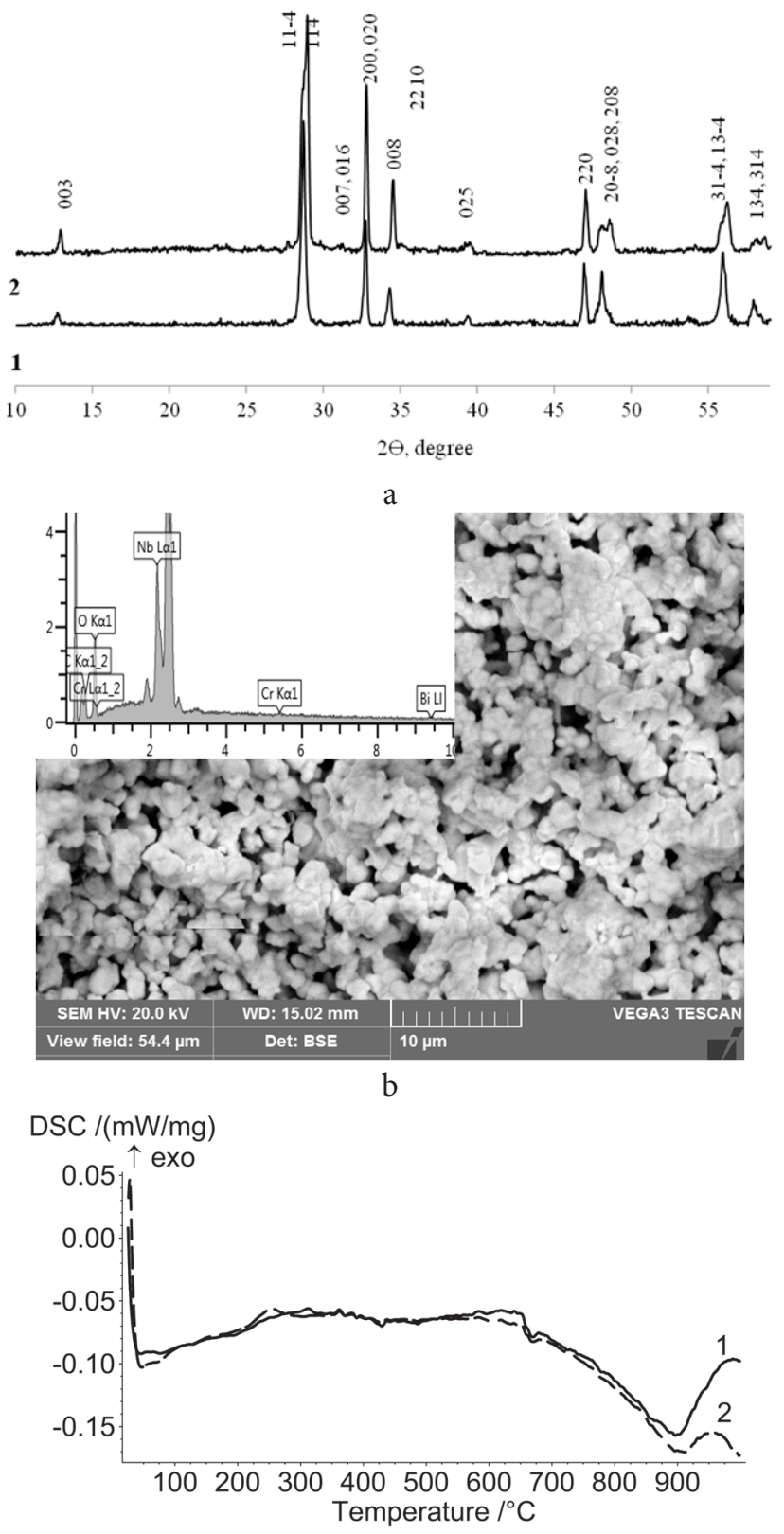

C

Fig. 1. The diffractograms of $\mathrm{Bi}_{5} \mathrm{Nb}_{3} \mathrm{O}_{15}$ (1) and $\mathrm{Bi}_{5} \mathrm{Nb}_{1.82} \mathrm{Cr}_{0.18} \mathrm{O}_{15-\delta}$ (2) (a); the energy dispersion spectrum and the surface microphotography of $\mathrm{Bi}_{5} \mathrm{Nb}_{1.82} \mathrm{Cr}_{0.18} \mathrm{O}_{15-\delta}$ (b); the thermograms of $\mathrm{Bi}_{5} \mathrm{Nb}_{3} \mathrm{O}_{15}(1)$ and $\mathrm{Bi}_{5} \mathrm{Nb}_{1.82} \mathrm{Cr}_{0.18} \mathrm{O}_{15-\delta}(2)$ (c).

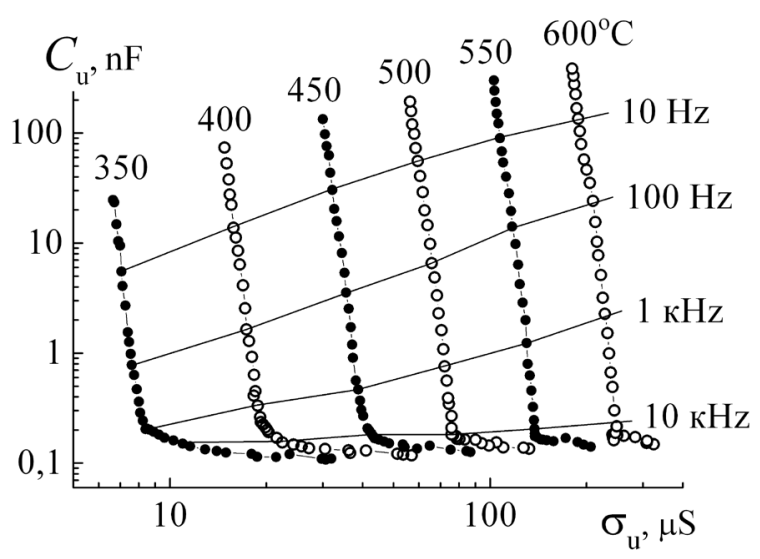

Fig. 2. The impedance hodographs of $\mathrm{Bi}_{5} \mathrm{Nb}_{3-3 x} \mathrm{Cr}_{3 x} \mathrm{O}_{15-\delta}(x=0,06)$ in logarithmic coordinates $\left(\sigma_{u}, C_{u}\right)$. 
components. Fig. 3 shows that with the increase in chromium concentration in the solid solutions, the impedance hodograph contracts to some minimum $(x=0.06)$ at first, and, after that, it begins to grow. As an example, Fig. 4 presents the impedance hodographs of $\mathrm{Bi}_{5} \mathrm{Nb}_{2.82} \mathrm{Cr}_{0.18} \mathrm{O}_{15-\delta}$ at $350,400,450,500,550$ and $600^{\circ} \mathrm{C}$. It should be noted that at high frequencies, the hodograph has a semi-circular form with the center located almost on the abscissa axis. Such a type of hodograph is typical for dielectric material with frequency-independent polarizability. Another polarization

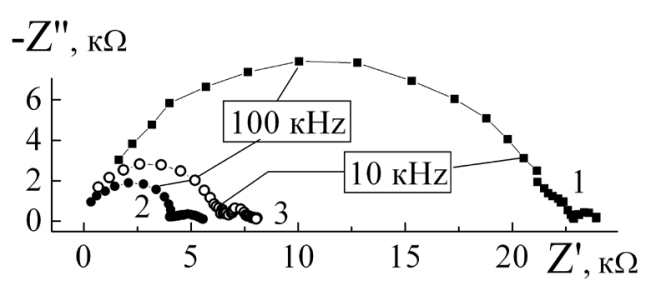

Fig. 3. The impedance hodographs of $\mathrm{Bi}_{5} \mathrm{Nb}_{3-3 x} \mathrm{Cr}_{3 x} \mathrm{O}_{15-\delta}$ at $x=0$ (1); $0.06(2)$ and $0.08(3)$, calculated at $600^{\circ} \mathrm{C}$.
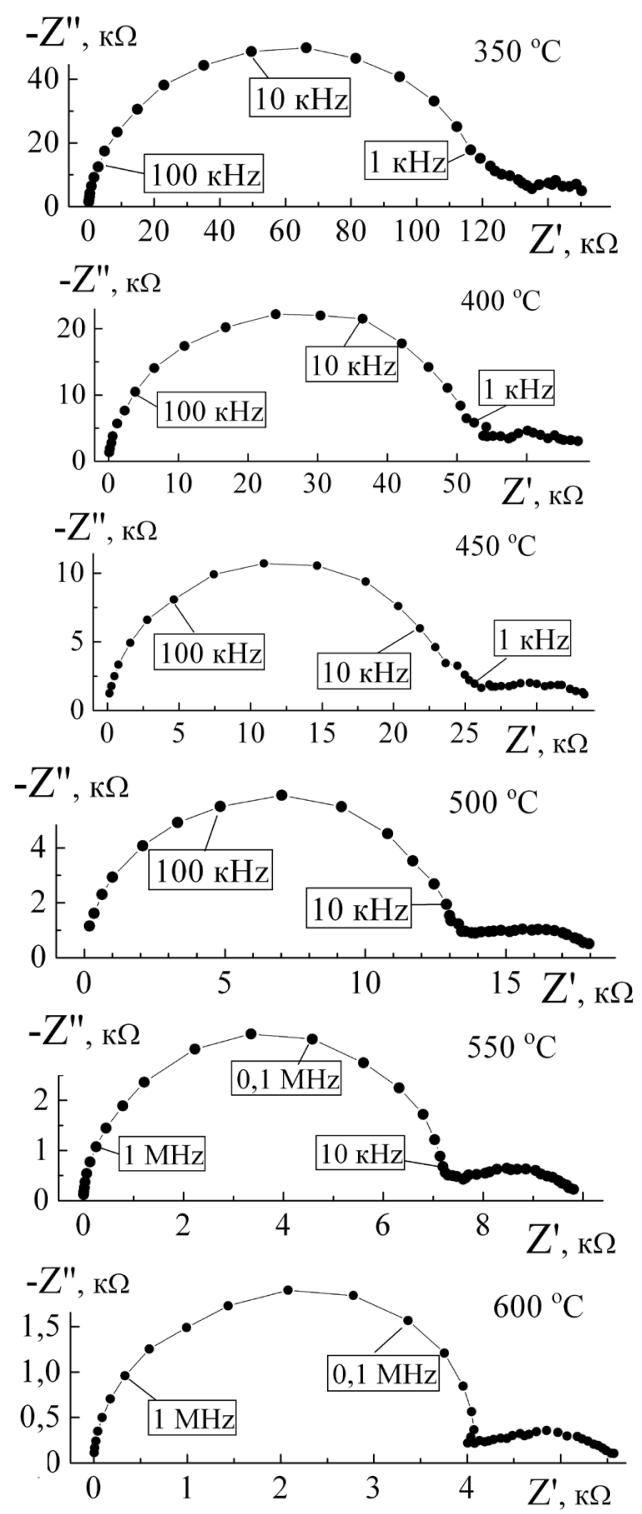

Fig. 4. The impedance hodographs of $\mathrm{Bi}_{5} \mathrm{Nb}_{1.82} \mathrm{Cr}_{0.18} \mathrm{O}_{15-\delta}$ in the range of $350-600^{\circ} \mathrm{C}$. process is observed at the frequency less than $1 \mathrm{kHz}$, its relative intensity is increasing as the temperature grows. This part of the hodograph has the form of an arc with the center located in the lower half-plane of the coordinate system. This is typical for a space distributed polarization process or for a complicated process with a wide spectrum of relaxation times.

The increase in the conductivity is observed as the temperature rises. Fig. 5 shows the temperature dependencies of the logarithm of conductivity of $\mathrm{Bi}_{5} \mathrm{Nb}_{3-3 x} \mathrm{Cr}_{3 x} \mathrm{O}_{15-\delta}$ with $x=0.06$ (1) and 0.08 (2) on reverse temperature. The dependency graphs obey the Arrhenius equation which made it possible to measure the conductivity activation energy $\left(E_{a}\right)$. The sample (1) has $E=0,62 \pm 0,01 \mathrm{eV}$; the sample (2) has $E=0,594 \pm 0,008) \mathrm{eV}$.

Although the activation energy differences are insignificant, the preexponential factor of the sample (1) is 1.9 times more than that of the sample (2). The calculations were made at the frequency of $1.4 \mathrm{~Hz}$ in the temperature range of $350-600^{\circ} \mathrm{C}$.

The most complete processing of impedance spectroscopy data can be made with the ZView software from Scribner Associates Inc. First of all, the equivalent circuits of all the samples were built (Fig. 6).

In the presented circuits, the resistors $R_{1}$ and $R_{2}$ along with two elements for space-distributed polarization were used. The constant phase element impedance $(C P E)$ was calculated using the formula (2):

$$
Z_{C P E}=\frac{1}{T_{C P E}(j \omega)^{P_{C P E}}} .
$$

Here $P_{C P E}$ is a phase shift constant; $T_{C P E}$ is a constant equal to the admittance module at $\omega=1 \mathrm{~Hz} ; j$ is an imaginary unit.

The element represented by $W_{s}$ is called a generalized finite-length Warburg element for transmissive $[15,16]$. This element simulates the process of diffusion of ions formed on one electrode to the opposite electrode and their reduction on it. The $W_{s}$ impedance was calculated using the formula:

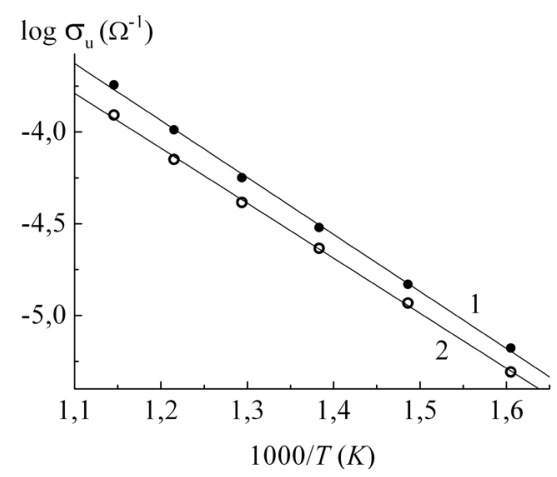

Fig.5. The temperature dependencies of the logarithm of conductivity of $\mathrm{Bi}_{5} \mathrm{Nb}_{3-3 x} \mathrm{Cr}_{3 x} \mathrm{O}_{15-\delta}$ with $x=0.06$ (1) and 0.08 (2).

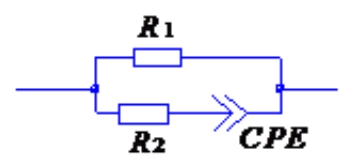

a

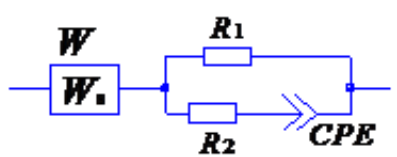

$\mathrm{b}$
Fig. 6. Equivalent circuits of $\mathrm{Bi}_{5} \mathrm{Nb}_{3-3 x} \mathrm{Cr}_{3 x} \mathrm{O}_{15-\delta}$ for the samples with different chromium content $(x): 0$ and 0,04 (a); 0,06 and 0,08 (b). 


$$
W_{s}=\frac{R}{(j \omega T)^{P}} \tanh \left[(j \omega T)^{P}\right] .
$$

Here $\tanh x$ is a hyperbolic tangent; $R, T$ and $P$ are parameters which depend on concentration and ion diffusion coefficient, electrode and volume characteristics of the sample. The accuracy of the equivalent circuits was checked by comparison of the experimental and theoretical curves (Fig. 7).

The visual control was accompanied by using accuracy evaluation by simulation errors. Tables 1 and 2 show the parameters of the equivalent circuits. Relative errors of the calculation are given in percentage and put into brackets. The double control of simulation accuracy is necessary because, in some cases, equivalent circuits of various structure provide nearly the same results.

We did not succeed in measuring the impedance spectra of the samples with $x=0$ and 0.12 at frequencies less than $1 \mathrm{kHz}$ due to noises, which indirectly point to the extremely low conductivity of the materials.

The important task of the impedance spectroscopy data analysis is the agreement of the equivalent circuit with the physical-chemical model of the sample. It is achieved by converting the equivalent circuit to the form where each parameter corresponds to a certain property of the sample, and a group of elements are responsible for a process. The

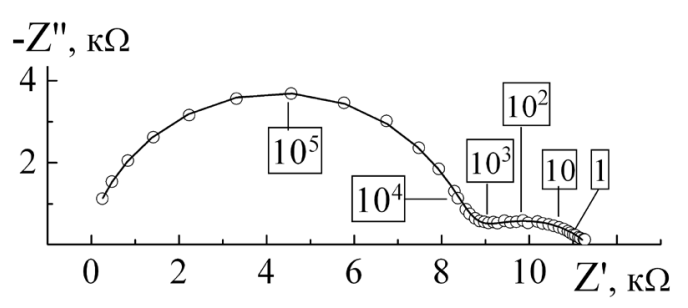

Fig. 7. The impedance hodograph of $\mathrm{Bi}_{5} \mathrm{Nb}_{3-3 x} \mathrm{Cr}_{3 x} \mathrm{O}_{15-\delta}$, measured at $550^{\circ} \mathrm{C}$ (dots) and calculated from the equivalent scheme (Fig. 2b) (solid line).

dipole $R_{1}-R_{2}(C P E)$ (Fig. 6) models electrical properties of the volume. Resistor $R_{1}$ sets the electric resistance of the medium (at $\omega=0$ ), that makes it possible to calculate the specific conductivity $(\sigma)$. In other words, $R_{1}$ is in charge of the active current passing through the sample. On the contrary, the dipole $R_{2}+C P E$ is responsible for the polarization (reactive) current which is characterized by three parameters in this particular case. The $P_{C P E}$ parameter sets the polarization process deflection of the discrete one. The discrete process is characterized by $P_{C P E}=1$, the $T_{C P E}$ constant being equal high-frequency electric capacity of the sample in farads. The less $P_{C P F}$, the wider the time relaxation spectrum of the polarization process. In this case, constant $T_{C P E}$ obtains fractional dimension which follows from the equation (2).

Table 1. Parameters of the equivalent circuits of $\mathrm{Bi}_{5} \mathrm{Nb}_{3-3 x} \mathrm{Cr}_{3 x} \mathrm{O}_{15-\delta}, x=0$ and 0.04 .

\begin{tabular}{|c|c|c|c|c|c|c|}
\hline$x$ & $t\left({ }^{\circ} \mathrm{C}\right)$ & $\begin{array}{c}\text { Frequency } \\
\text { interval }(\mathrm{kHz})\end{array}$ & $R_{1}(\mathrm{kOhm})$ & $R_{2}(\mathrm{Ohm})$ & $T_{C P E} / 10^{-10}$ & $P_{C P E}$ \\
\hline \multirow{3}{*}{0} & 400 & $10-1000$ & $7160(3)$ & $-1680(12)$ & $13.1(8)$ & $0.753(0.8)$ \\
& 450 & $10-1000$ & $251(2)$ & $-1150(12)$ & $18.4(7)$ & $0.737(0.7)$ \\
& 500 & $5-1000$ & $95.8(0.8)$ & $-596(12)$ & $17.9(5)$ & $0.746(0.5)$ \\
& 550 & $10-1000$ & $42.4(1)$ & $-186(38)$ & $14.6(8)$ & $0.767(0.7)$ \\
& 600 & $10-500$ & $19.6(0.6)$ & $290(40)$ & $9.1(11)$ & $0.808(1)$ \\
\hline \multirow{3}{*}{0.12} & 400 & $10-1000$ & $2524(10)$ & $-515(60)$ & $2.78(11)$ & $0.870(1)$ \\
& 450 & $1-1000$ & $889(2)$ & $-123(80)$ & $2.01(5)$ & $0.894(0.4)$ \\
& 500 & $25-1000$ & $423(3)$ & $-76(184)$ & $2.05(9)$ & $0.895(0.8)$ \\
& 550 & $1-300$ & $198(1)$ & $516(74)$ & $1.61(10)$ & $0.914(0.8)$ \\
& 600 & $1-500$ & $86.95(0.7)$ & $632(29)$ & $2.19(8)$ & $0.896(0.7)$ \\
\hline
\end{tabular}

Table 2. Parameters of the equivalent circuits of $\mathrm{Bi}_{5} \mathrm{Nb}_{3-3 x} \mathrm{Cr}_{3 x} \mathrm{O}_{15-\delta}, x=0.06$ and 0.08 .

\begin{tabular}{|c|c|c|c|c|c|c|c|c|}
\hline$x$ & $t\left({ }^{\circ} \mathrm{C}\right)$ & $R(\mathrm{kOhm})$ & $T(\mathrm{~ms})$ & $P$ & $R_{1}(\mathrm{kOhm})$ & $R_{2}(\mathrm{Ohm})$ & $T_{C P E} / 10^{-10}$ & $P_{C P E}$ \\
\hline \multirow{6}{*}{0.18} & 400 & $12.1(8)$ & $18(21)$ & $0.371(10)$ & $57.4(1.2)$ & $-228(26)$ & $3.66(6)$ & $0.928(0.6)$ \\
& 450 & $7.55(3.7)$ & $25(11)$ & $0.297(5)$ & $28.8(0.7)$ & $-256(13)$ & $5.48(3)$ & $0.908(0.3)$ \\
& 500 & $5.1(3.7)$ & $23(11)$ & $0.256(5)$ & $14.87(0.9)$ & $-280(11)$ & $6.41(3)$ & $0.903(0.3)$ \\
& 550 & $3.24(2.4)$ & $14(7.6)$ & $0.250(3)$ & $8.10(0.7)$ & $-221(6,6)$ & $6.77(3)$ & $0.903(2.6)$ \\
& 600 & $1.98(1.3)$ & $9.7(4.5)$ & $0.235(2)$ & $4.37(0.4)$ & $-167(3,6)$ & $6.08(2)$ & $0.913(2)$ \\
\hline \multirow{6}{*}{0.24} & 450 & $9.07(5)$ & $4.05(14)$ & $0.240(5)$ & $25.61(1.6)$ & $-680(17)$ & $2.51(5)$ & $0.929(0.5)$ \\
& 500 & $3.88(6)$ & $16.3(16)$ & $0.209(7)$ & $15.18(1)$ & $-403(15)$ & $6.86(3)$ & $0.864(0.4)$ \\
& 550 & $2.78(4)$ & $13.6(12)$ & $0.216(5)$ & $8.48(0.9)$ & $-297(8)$ & $5.93(4)$ & $0.877(0.3)$ \\
& 600 & $2.149(2)$ & $9.4(6)$ & $0.226(2)$ & $4.45(0.6)$ & $-170(7)$ & $4.35(4)$ & $0.901(0.3)$ \\
\hline
\end{tabular}


The resistor $R_{2}$ corrects the angle value of dielectric losses $\delta$ of the $R_{2}+C P E$ circuit. This element is needed as $\operatorname{tg} \delta_{C P E}$ is a constant: $\operatorname{tg} \delta_{C P E}=\operatorname{ctg}\left(\pi P_{C P E} / 2\right)$. At $R_{2}<0$, the dielectric losses decrease, but they increase if $\mathrm{R} 2>0$. Thus, the key characteristics of the medium can be calculated from the equivalent circuits. In should be mentioned that $\varepsilon$ and $\operatorname{tg} \delta$ will depend on frequency which differs them from frequency independent parameters given in Table 1 and $2 . W_{s}$ in the equivalent circuits of the samples with $x=0.18$ and 0.24 (Fig. 6b) indicates the ion charge transfer. The parameters given in Table 2 characterize the ionic conductivity to the full extent. Notice that both samples are almost identical by the ionic conductivity, and markedly different by the volume properties (Fig. 3).

According to the electrochemical impedance theory [15], the parameter $R$ corresponds to the energy loss during diffusion of ions and it is expressed in Ohms. The ionic resistance is responsible for energy losses during the ion drift (moving in an electric field). These two variables are of the same nature (collisions of ions with the lattice and with each other) and are fairly close in their magnitudes. Thus, we can take $R$ as the ionic resistance. The parameter $R_{1}$ specifies the frequency-independent resistance of the volume part. Ions cannot move over significant distances at $1 \mathrm{MHz}$, but electrons can. Therefore, $R_{1}$ can be taken as the electronic resistance. Consequently, $I_{\text {ion }} / I_{\text {electron }} \approx R_{1} / R$. Table 2 gives evidences that when the electric field is turned on, the ionic current can be from 2 to 4 times greater than the electronic current (depending on the temperature and composition of the samples). Since there is no external ion source, after the transient process, the ionic current is depleted to zero and only the electronic current limited by the resistor $R_{1}$ remains.

Thus, building of adequate electric models of the samples makes it possible to express all commonly used characteristics of materials through equations. This provides a possibility for a more thorough analysis of impedance spectra results using various mathematical methods.

\section{Conclusion}

The studies of electrical properties of bismuth niobate $\mathrm{Bi}_{5} \mathrm{Nb}_{3} \mathrm{O}_{15}$ and chromium-containing solid solutions $\mathrm{Bi}_{5} \mathrm{Nb}_{3-3 x} \mathrm{Cr}_{3 x} \mathrm{O}_{15-\delta}(x \leq 0.08)$ using impedance spectroscopy did not reveal any phase transition in the samples in the temperature range of $350-600^{\circ} \mathrm{C}$. For $\mathrm{Bi}_{5} \mathrm{Nb}_{3} \mathrm{O}_{15}$ and the solid solutions, the parameters of equivalent circuits were calculated and the electric models were built, which adequately describe the characteristics of materials. At the temperatures higher than $300^{\circ} \mathrm{C}$, the samples $\mathrm{Bi}_{5} \mathrm{Nb}_{3-3 x} \mathrm{Cr}_{3 x} \mathrm{O}_{15-\delta}$ exhibited semiconducting properties with activation energy of conductivity $\sim 0.6 \mathrm{eV}$. The performed studies resulted in a conclusion about the mixed electronicionic character of conductivity of the $\mathrm{Bi}_{5} \mathrm{Nb}_{3-3 x} \mathrm{Cr}_{3 x} \mathrm{O}_{15-\delta}$ solid solutions.

\section{References}

1. G. A. Smolenskij, V. A. Bokov, V. A. Isupov et al. L. Nauka, 1985. 396 p. (in Russian) [Г. А. Смоленский, В. А. Боков, В. А. Исупов и др. Л. Наука, 1985. 396 с.]

2. L.A. Ivanova, Yu. N. Venevcev. M.: Niitehkhim, 1983. 99 p. (in Russian) [Л.А. Иванова, Ю.Н. Веневцев. М. НИИТЭХИМ, 1983. 99 с.]

3. G. A. Smolensky, V.A. Isupov, A.I. Agranovskaya. Sov. Phys. Sol. St. 1, 149 (1959). (in Russian) [Г. А. Смоленский, В.А. Исупов, А.И. Аграновская, Физика твердого тела, 1, 169 (1959).]

4. J. Gopalakrishnan, A. Ramanan, C.N. R. Rao, D. A. Jefferson, D. J. Smith. J. Sol. St. Chem, 55,101 (1984). DOI: 10.1016/0022-4596(84)90252-4.

5. A. Lisinska-Czekaj, D. Czekaj, Z. Surowiak et al. J. of Eur. Ceram. Soc. 24, 947, 2004. DOI:10.1016/S09552219(03)00429-1.

6. T. Takenaka, K. Komura, K. Sakata, Jpn. J. Appl. Phys. 35, 5080 (1996). DOI:10.1143/JJAP.35.5080.

7. N.A. Zhuk, I. V. Piir, Inorgan. Mat., 44, 1362 (2008). (in Russian) [Н. А. Жук, И. В. Пийр, Неорг. матер., 44, 1504 (2008).] DOI: 10.1134/S0020168508120182

8. N. A. Zhuk, I. V. Piir, N. V. Chezhina, Rus. J. Gen. Chem. 78, 376 (2008). (in Russian) [Н. А. Жук, И. В. Пийр, H.В. Чежина, ЖОХ, 78, 393 (2008).] DOI: 10.1134/ S1070363208030079

9. N.A. Zhuk, I.V. Piir, A.L. Pimenov, N.V. Chezhina, Rus. J. Gen. Chem. 78, 335 (2008). (in Russian) [Н. А. Жук, И.В.Пийр, А. Л. Пименов, Н. В. Чежина, ЖОХ, 78, 353 (2008).] DOI: 10.1134/S1070363208030079

10. N.A. Zhuk, I.V. Piir, A.L. Pimenov, N.V. Chezhina. Rus. J. Gen. Chem. 77, 990 (2007). (in Russian) [Н. А. Жук, И. В. Пийр, А. Л. Пименов, Н. В. Чежина, ЖОХ, 77, 898 (2007).] DOI: 10.1134/S1070363207060059

11. L. G. Akselrud, Yu. N. Gryn, P. Yu. Zavalij, Thes. Rep. 12th Eur. Crystallogr. Meet. 155 (1985).

12. V. K. Yanovskij, V.I. Voronkova, I. N. Leonteva, Inorgan. Mater. 26, 1154 (1990). (in Russian) [В.К. Яновский, В. И. Воронкова, И. В. Водолазская, Неорг. матер., 26, 1297 (1990).]

13. V.K. Yanovskij, V.I. Voronkova, I. N. Leonteva, Inorgan. Mater. 25, 706 (1989). (in Russian) [В.К. Яновский, В.И. Воронкова, И.Н. Леонтьева, Неорг. матер., 25, 834 (1989).]

14. N.A. Sekushin. Russ. J. Elektrochem., 45, 1300 (2009). (in Russian) [Н.А. Секушин, Электрохимия, 45, 1403 (2009).] DOI: 10.1134/S1023193509110123

15. A. Lasia. Electrochemical Impedance Spectroscopy and its Applications. New York: Springer Science+Business Media, 369 p (2014).

16. P.T. Oreshkin. Fizika poluprovodnikov i diehlektrikov. M.: Vysshaya shkola. 448 p. 1977. (in Russian) [П.Т. Орешкин. Физика полупроводников и диэлектриков. М. Высш. Школа. 448 С. (1977).] 